\title{
Timing and nature of silica enrichment in the Kaapvaal lithospheric mantle
}

\author{
L.J. WASCH (1), F.M. VAN DER ZWAN (1), G.R.DAVIES (1), O.NEBEL (1), \\ M.L.A.MOREL (1) E.W.G. HELLEBRAND (2)
}

(1) Department of Petrology, Vrije Universiteit Amsterdam, NL. (2) SOEST - University of Hawaii, USA.

The Archaean lithospheric mantle of the Kaapvaal Craton is residual after extensive melt removal but in Fig. 1 the silica content is above the oceanic melting trend and cannot by explained by melting models alone (e.g. Boyd, 1989; Walter, 1998). In addition, the peridotites are often enriched in incompatible trace elements (see recent discussion in Simon et al. 2007). The high silica content, manifested as high modal orthopyroxene $(\mathrm{Opx})$, requires a silica enrichment process. However, the timing and nature of the silica enrichment process is not well understood, partly because interpreting the temporal evolution of mantle xenoliths is complicated by more recent metasomatism and melt interaction during transport by kimberlite. In an effort to constrain the Opx addition process, we report a combined petrology and in-situ major and trace element (SIMS) and mineral Nd-Hf-Os isotope study of extremely silica-rich and non-deformed xenoliths from Kimberley, South Africa.

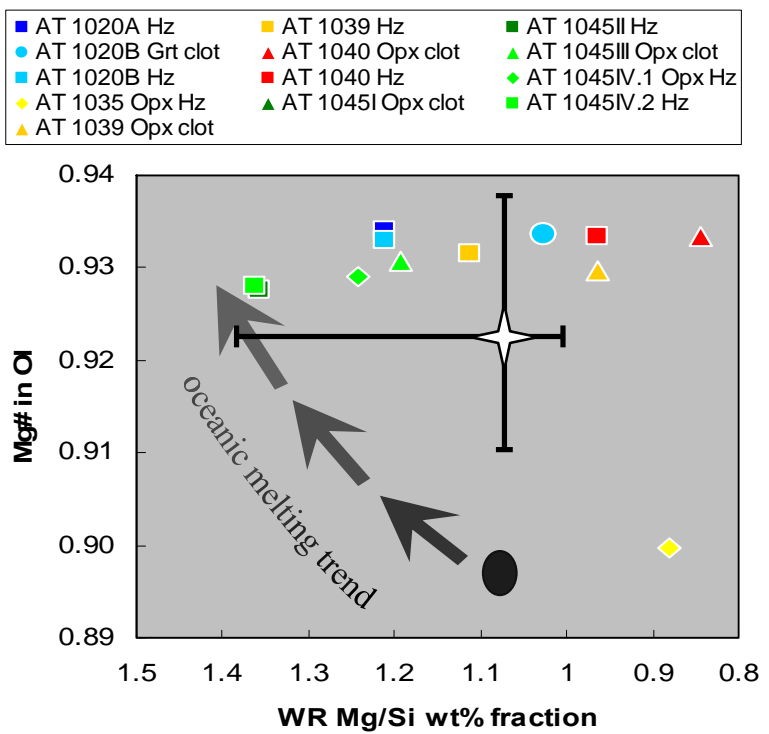

Fig. $1 \mathrm{Mg} \#$ in $\mathrm{Ol}-\mathrm{WR} \mathrm{Mg} / \mathrm{Si} \mathrm{wt} \%$ (Boyd, 1989). The studied samples plot above the 'oceanic melting trend'. Black spot: primitive mantle. White star and black lines: Kaapvaal average and compositional range (Pearson et al., 2003).

Extreme Si-enrichment is manifested in two forms: I) Opx-rich clots and veins $(5-20 \mathrm{~cm})$ that have garnet (Gnt) exsolution; average modal content of the Opx clots: 75\% Opx, 15\% Gnt, $10 \%$ olivine (Fig. 2). II) Gnt-rich clots up to $5 \mathrm{~cm}$; average modal content of the Gnt clots: $80 \%$ Gnt, 15\% Opx, $5 \%$ Ol (Fig. 3).

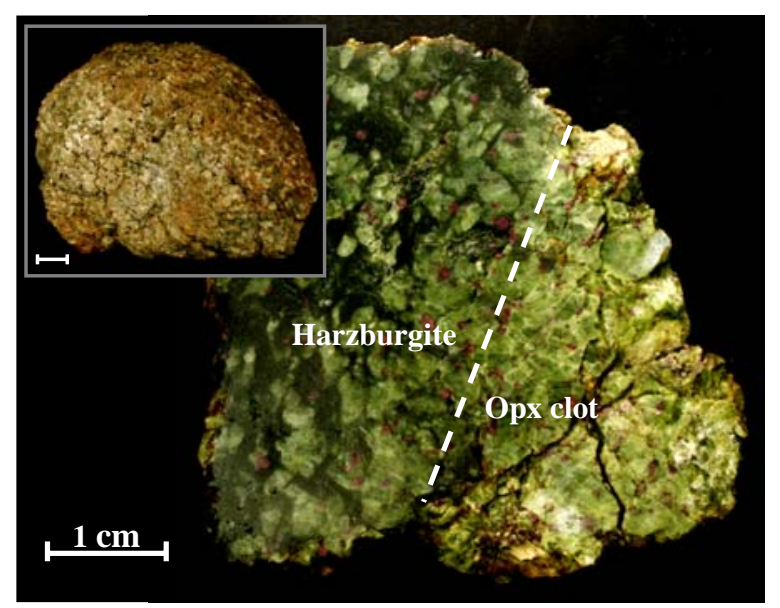

Fig. 2 Opx clot characterized by high Opx content compared to the harzburgite; sample AT 1040.

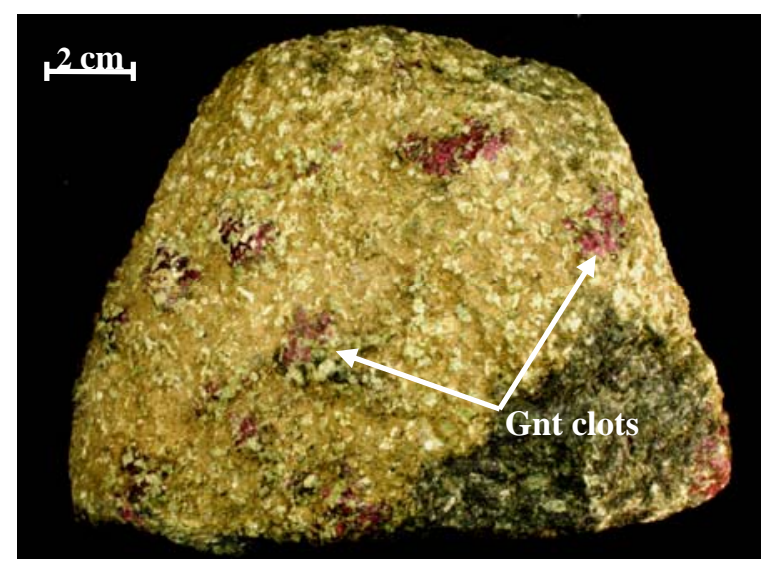

Fig. 3 Gnt clots in depleted harzburgite; sample AT 1020.

Major element compositions of host peridotites and clots are extremely depleted in $\mathrm{FeO}$ and hence have a high Mg\# (Ol Mg\#: 0.93). Furthermore, the samples are also extremely depleted in incompatible elements, indicating large amounts of melt extraction. The samples of this study are more Si-rich than previously reported for Kaapvaal peridotite whole rock compositions; $\mathrm{SiO}_{2}$ is up to $55 \mathrm{wt} \%$ (Fig. 4) and represent among the most extremely $\mathrm{SiO}_{2}$ enriched peridotites yet recorded. The Opx clots are enriched in $\mathrm{SiO}_{2}, \mathrm{Al}_{2} \mathrm{O}_{3}, \mathrm{~K}_{2} \mathrm{O}, \mathrm{CaO}, \mathrm{Cr}_{2} \mathrm{O}_{3}, \mathrm{~V}$, and lower in $\mathrm{FeO}$, $\mathrm{MgO}$ and $\mathrm{NiO}$. The Grt clots have elevated $\mathrm{Al}_{2} \mathrm{O}_{3}$, $\mathrm{CaO}, \mathrm{MnO}, \mathrm{K}_{2} \mathrm{O}$ and $\mathrm{V}$ contents. 


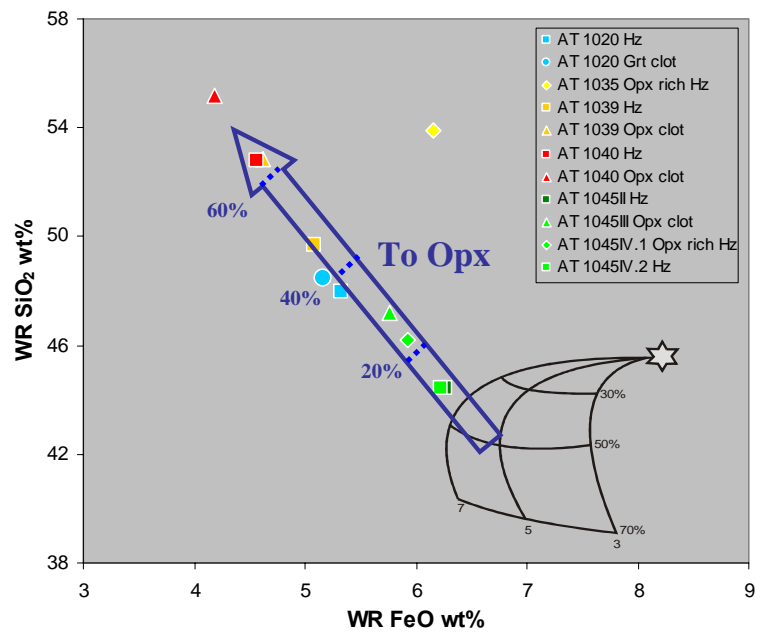

Fig. 4. $\mathrm{SiO}_{2}$ vs. $\mathrm{FeO}$ diagram. Samples have significantly higher $\mathrm{SiO}_{2}$ and lower $\mathrm{FeO}$ contents than can be explained by melting at $3 \mathrm{GPa}$ to 7 (Walter, 1998).

Metasomatism associated with clot formation does not appear to have affected harzburgite HREE contents. Therefore, HREE can be used to study melt depletion. Reconstructed harzburgite-lherzolite whole rock HREE contents vary by more than an order of magnitude and are low $\left(\mathrm{Yb}_{\mathrm{N}}=0.02-0.4\right.$; fig. 5). Coupled with the positive Er-Yb slopes of some samples, these low HREE contents suggest that the harzburgite protoliths were formed at least partially by melt depletion in the spinel-stability field. The current presence of Gnt implies that following initial melting, the harzburgites were tectonically transported to a deeper level before kimberlite eruption. The depleted character of the major elements requires high degrees of melting (40$50 \%$ ). The HREE content can be explained by $\leq 20 \%$ melting in the spinel-stability field. Hence melting must have been polybaric and was initiated in the Grt stability field.

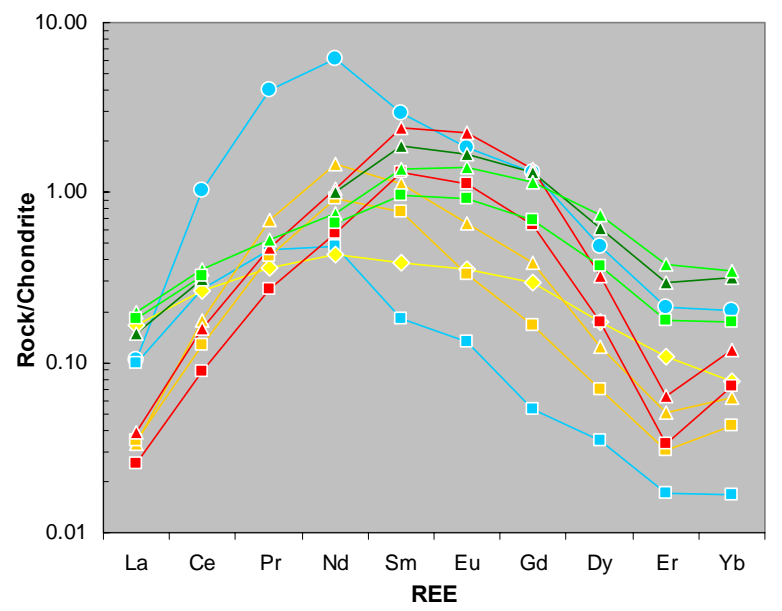

Fig. 5 - Reconstructed WR-REE concentrations. For legend see Fig. 1.

Some of the Si-enriched samples appear recently metasomatised (AT 1045). This process is manifested by clinopyroxene (Cpx) addition and is associated with relative LREE enrichment; $\mathrm{La}_{\mathrm{N}}$ of a lherzolite is 10 times higher compared to harzburgite AT 1040 (Fig.
5). Neodymium mineral (Gnt-Opx-Cpx) isochron ages of the Cpx-metasomatised rocks (AT 1045; Fig. 6) are within error of the age of kimberlite eruption ( $90 \mathrm{Ma})$ indicating syn-eruption metasomatism. Mineral $\varepsilon_{\mathrm{Hf}(\mathrm{t})}$ and $\varepsilon_{\mathrm{Nd}(\mathrm{t})}$ values are close to kimberlitic values (AT 1045 Fig. 7) indicating that Cpx formation was related to kimberlite magmatic activity. This led to extensive chemical equilibration within the metasomatised peridotites.

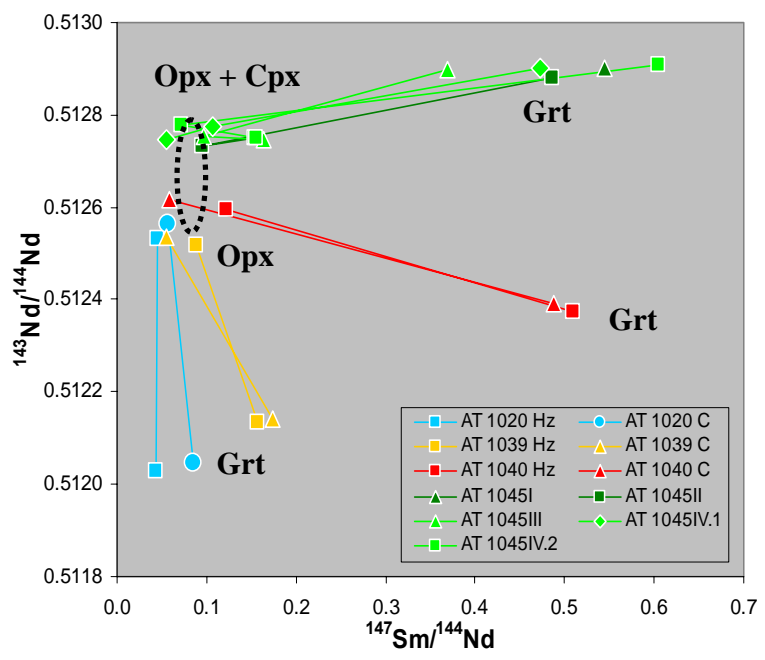

Fig. $6 \mathrm{Sm}-\mathrm{Nd}$ diagram indicating disequilibrium between minerals. Black circle: kimberlitic values (Nowell, 2004).

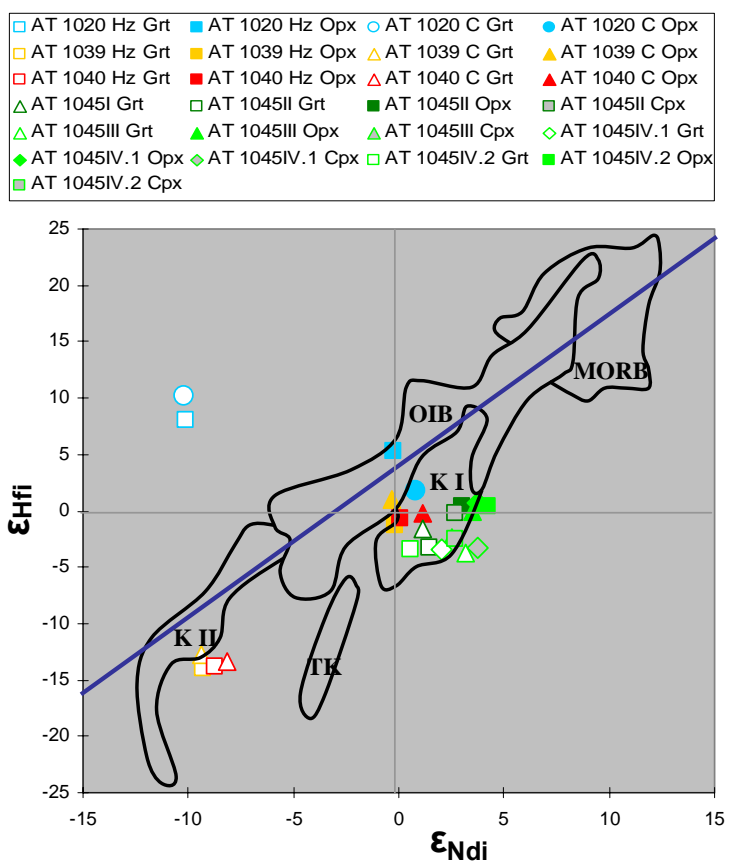

Fig. $7 \varepsilon H f$ vs. $\varepsilon N d$ diagram. The rocks of this study are plotted together with fields for MORB, OIB and kimberlites (KI: kimberlite I, KII: kimberlite II, TK: transitional kimberlite; Nowell, 2004).

Non Cpx-bearing Opx and Gnt-clots have depleted HREE, but are relatively enriched in MREE and LREE. The resulting whole rock REE pattern is " $\mathrm{S}$ " shaped with a maximum at $\mathrm{Sm}-\mathrm{Nd}$ (Fig. 5). The theoretical trace element concentrations of the agent in equilibrium with Gnt and Opx are calculated from trace 
element concentrations of the minerals and distribution coefficient to assess the nature of the modifying agent. Melts in equilibrium with Opx have trace elements contents similar to kimberlite, indicating melt-rock interaction. Garnet appear relatively unaffected by kimberlite interaction and a liquid in equilibrium with gnt may represent the trace element composition of the Si-enrichment agent (Fig. 8). The low HREE contents and strong fractionation are not indicative of a melt, but rather of a fluid (Stachel and Harris, 1997); in agreement with suggestion by Simon (2004) and Bell et al. (2005). High precision HFSE studies are currently underway to substantiate these findings.

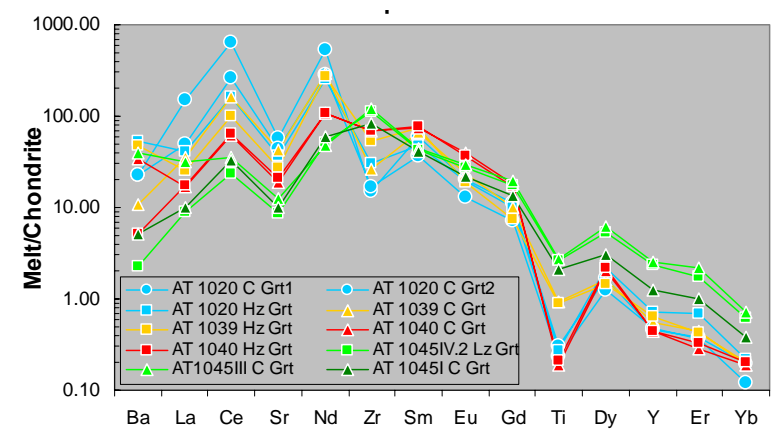

Fig. 8 Trace element concentrations of a metasomatic agent in equilibrium with Gnt.

The Gnt in the Opx-clots (AT 1039, AT 1040) have low Lu/Hf (with low time-integrated $\varepsilon_{\mathrm{Hf}(\mathrm{t})}-15$; Fig. 7), whereas the Gnt-clots (AT 1020) have high Lu/Hf $\left(\varepsilon_{\mathrm{Hf}(\mathrm{t})}+10\right)$. The Gnt-clots, as well as the Opx-clots, have low $\mathrm{Sm} / \mathrm{Nd}$ and $\mathrm{Nd}$ isotope ratios $\left(\varepsilon_{\mathrm{Nd}}-10\right)$. In agreement with the trace element data, Opx of the Gntand Opx clots have a kimberlite Nd-Hf isotope signal; therefore Opx-Gnt mineral isochrons do not provide geological significant age constraints on the enrichment process (Fig. 6). Gnt Hf and $\mathrm{Nd}$ model ages indicate that the Opx clots formed $>2 \mathrm{Ga}$, while the Gnt clots have model ages of $>1 \mathrm{Ga}$. This implies that Opx and Gnt clots were not formed simultaneously and two enrichment events are required. An ancient model age of Opx clot AT 1039 is confirmed by a Re depletion age of $2.8 \pm 0.1 \mathrm{Ga}$. However, Re depletion age of the

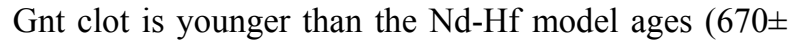
$100 \mathrm{Ma}$ ). These data suggest that the melt-fluid-rock interaction responsible for the Gnt clot led to a mixture of age information. However, the combined Hf-Nd-Os data confirm that the metasomatism that formed the Gnt clots is significantly younger $(>1 \mathrm{Ga})$ than that responsible for the Opx clots.

The combined trace element and isotopic data are used to formulate a model for the nature and timing of the silica addition to the Kaapvaal lithosphere (Fig. 9).

This model involves extensive melt depletion in the Archaean (I). The mantle was enriched in $\mathrm{SiO}_{2}$ at $>2$ $\mathrm{Ga}$ (II); modification is probably related to interaction with fluids that were released during subduction of the Kimberley block beneath the Witwatersrand block. A second metasomatic enrichment formed Gnt clots; however, the tectono-magmatic event responsible for this event is poorly constrained (III). At $\sim 90 \mathrm{Ma}$, kimberlite eruption brought the xenoliths to the surface. Before or during entrainment, interaction with the kimberlitic magmatism caused widespread metasomatism and the introduction of Cpx (IV).

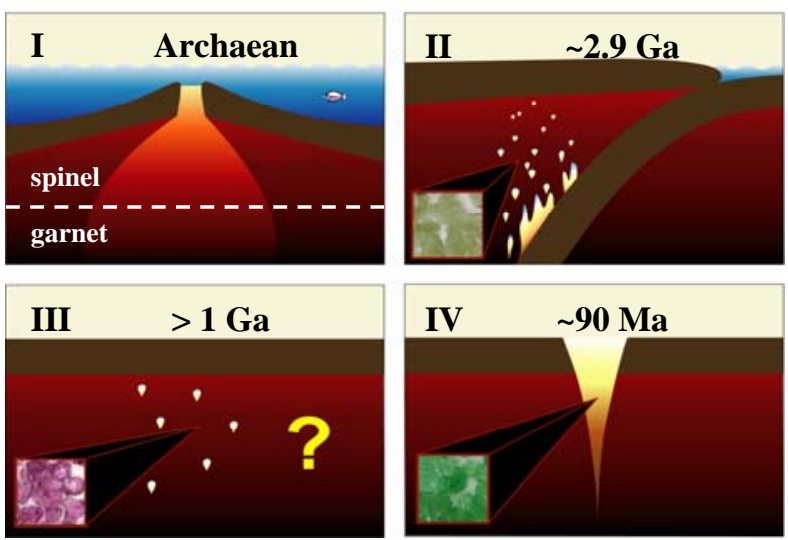

Fig. 9 Model for the evolution of the Kaapvaal mantle, see text for explanation.

\section{References}

Bell, D.R., Gregoire, M., Grove, T.L., Chatterjee, N., Bowring, S.A., Carlson, R.W. Buseck, P.R. (2005) Silica and volatile-element metasomatism of Archean mantle: a xenolithscale example from the Kaapvaal Craton. Contributions to Mineralogy and Petrology 150, 251-267.

Boyd, F.R., 1989. Compositional distinction between oceanic and cratonic lithosphere. Earth and Planetary Science Letters 96, 15-26.

Nowell, G.M., Pearson, D.G., Bell, D.R., Carlson, R.W., Smith, C.B., Kempton, P.D., Noble, S.R., 2004. Hf Isotope Systematics of Kimberlites and their Megacrysts: New Constraints on their Source Regions. Journal of Petrology 45, $1583-$ 1612.

Pearson, D.G., Canil, D., Shirey, S., 2003. Mantle Samples Included in volcanic Rocks: Xenoliths and Diamonds. Treatise on Geochemistry 1-106.

Simon, N.S.C., 2004. The Formation and Modification of Cratonic Lithospheric Roots - A Petrological and Geochemical Study of Xenoliths from the Kaapvaal Craton. Academisch Proefschrift, Vrije Universiteit Amsterdam.

Simon, N.S.C., Carlson, R.W., Pearson, D.G., Davies, G.R., 2007. The origin and evolution of the Kaapvaal cratonic lithospheric mantle. Journal of Petrology 48, 589-625.

Stachel, T. and Harris, J.W., 1997. Diamond precipitation and mantle metasomatism evidence from the trace element chemistry of silicate inclusions in diamonds from Akwatia, Ghana. Contributions to Mineralogy and Petrology 129, 143-154.

Walter, M.J., 1998. Melting of garnet peridotite and the origin of komatiite and depleted lithosphere. Journal of Petrology 39, 29-60. 